\title{
TED Talks as an ICT Tool to Promote Communicative Skills in EFL Students
}

\author{
Martínez Hernández María A. ${ }^{1}$ Vargas Cuevas Junior A ${ }^{1} \&$ Ramírez Valencia Astrid ${ }^{1}$ \\ ${ }^{1}$ Universidad Distrital Francisco Jose de Caldas, Faculty of Science and Education Bogotá, Colombia. \\ Correspondence: Martínez Hernández María A, Science and Education, Distrital University, Bogotá, Colombia.
}

Received: October 2, 2018 Accepted: November 15, 2018 Online Published: November 18, 2018

doi: 10.5539/elt.v11n12p106 URL: https://doi.org/10.5539/elt.v11n12p106

\begin{abstract}
In many EFL classrooms in Colombia, it is evident how students struggle trying to use English to communicate; nonetheless, with the revolution of ICTs that has taken place in the last years, there is a variety of tools available to support English learning autonomously with applications, blogs, and online courses; however, many of these tools were not originally designed for teaching but can be adapted for such purpose. TED is a website and a downloadable application where videos are shared in which you can see a wide variety of English speakers born in many parts around the world speaking in a fun and familiar manner with the audience about various topics of interest that besides, come along with cultural content, which extends the range of accents, words, expressions, and ways of referring to the same topic. In this action research, we propose a reflection on the incidence of TED talks on the teaching and learning of English as a foreign language. The instruments used to collect data were interviews, questionnaires, and teacher journals. The use of these videos provided the students with all the communicative elements that allowed them to use English to express their ideas. This offers a glimpse of how useful authentic videos and subtitles are when encouraging students to learn English.
\end{abstract}

Keywords: language learning, communicative skills, TED talks, technologies, and EFL

\section{Introduction}

Nowadays, learning a second language is a necessity in different areas of the life. In Colombia, there is a low level of English proficiency according to Education first that every year publishes the results of studies about English in Latin America. (La república, 2016). This is an alarming situation considering the importance of that language; for that reason, teachers, and institutions must rethink strategies, tools, and methodologies that are being used to teach English to discover new and meaningful ways to teach languages in a technological era. It is crucial since children nowadays have contact with technology and the internet all the time (Henríquez, Moncada, Chacón, Dallos, \& Ruiz, 2012).

That means children and people, in general, have access to different tools such as digital platforms that are to entertain and get information; for instance, TED Talk (Technology, Entertainment, and Design) or YouTube where there are videos about different topics. In TED's case, there are videos of conferences given on different topics like sports, culture, fashion, politics, technology, etc. by speakers from all around the world speaking in English. For that reason, there are many kinds of accents, words, and expressions that can be used in an English class in a didactic and funny way.

\section{Topic and context}

According to the Colombian government, Colombia should be bilingual by 2019. They claim that just with curriculum students will be able to communicate and develop a proper level of proficiency to communicate in English. The objectives set out by the Education Ministry, in the documents named Estándares Básicos de Competencias en Lenguas Extranjeras: Inglés (2006) and Derechos Básicos de Aprendizaje: inglés (2016), following the European Common Framework for school students are as follows: from grades $1^{\text {st }}$ to $3^{\text {rd }}$ students must be in A1 level, from $4^{\text {th }}$ to $7^{\text {th }}$ in A2 level and from $8^{\text {th }}$ to $11^{\text {th }}$ students must be in B1 level; Besides, university students from any career must be in B2 level and English undergraduate students must be in $\mathrm{C} 1$. However, one can realize that students do not have the expected communicative competence when they finish high school. It means that even they have been learning some structures and features of the language, the lack of usage does not bolster the motivation to speak. 
Evidence of the above can be found in the results given by the ICFES, where students on average, in 2016, do not overcome the A2 level. Considering that when finishing their studies, students should have a B1 level, these results show that either the policies carried out by the government nor the methodologies used inside the classroom are being effective. This is related with the way teachers assume the English teaching as a foreign language that dates from the 50s. According with Arias, Buitrago and Pineda (2011), teachers are reluctant to implement new technologies inside the classroom because they think that it is a manner of losing their identity, and their autonomy which concurs with Jalabe et al. (2018) that establish in their study how the attitudes towards the ICT's hamper the implementation of novel resources inside the classroom.

So, approaching this concern, we are looking to give the students with tools that allow them to express their ideas and feel confident when doing it. That is, through the use of TED: a platform where interesting videos about a wide variety of topics spoken by specialist people in a natural and authentic way can be found. Given that there have been some attempts to implement such a strategy that permits getting a glimpse on how useful this tool can be (Quizhpi, 2015; Bianchi, F. y Marenzi, I., 2015). It is important to highlight that most of the studies have been developed in Asia and Europe. Considering that in Colombia there is little interest in the implementation of technological tools; this field has been poorly studied. In this manner, this action research aims to analyze how authentic videos with cultural content that come from digital platforms as a technological resource such as TED, contribute to the promoting of the oral use of English language in eleventh graders from a public School.

\section{Theoretical Framework}

In this section, the reader can find previous studies related to the use of mass media and technological devices in the English classroom; in addition, are the three main concepts that were taken into account provided those were the principal terms that guided our study.

\subsection{Literature Review}

It is important to remark that we did not find studies about the use of TED in the classroom in Colombia; however, there were some others regarding the use of authentic videos as a tool in EFL classes to improve the communicative skills, which we consider, are relevant to our study.

We can start by giving a brief description of a study that was held at Prado Veraniego School located in Suba, 32 Students in the first grade of primary are individuals between 5 and 7 years old called "technologies for EFL beginners: the video as a technological resource that allows the design of adequate material to initiate learning processes in EFL for first grade students at Prado Veraniego school" (2014) made by a student from Universidad Pedagógica Nacional. This first research aimed to prove how the use of videos allows the development of listening and oral skills in students who see English lessons for the first time. This through the design of specific material for the population, which is based on the videos that are presented to students and that are part of the television programs that students watch usually.

Cruz, Suárez (2014) concluded that:

...the specific characteristics of the video such as movement, sound, and color, permit students to get engaged, be motivated, and understand the topics presented easily; thus, students remember vocabulary easily, faster and improve significantly their listening skill than when the class does not involve videos. Also, it provides students with tools that permit them to understand the world, more than just receiving constant information from the media without making any analytical process; Thus, students recalled vocabulary easily and faster. (p.77)

This research is related to ours in the pedagogical use of videos; however, the focus is not in the video but in the design of specific material for first graders; in other words, in the present study videos are the main tool to promote the use of English language inside the classroom because of their cultural content while in the previous one, videos are used as a base resource to create appropriate material for class.

Secondly, there is a study that was conducted based on the use of authentic material from the digital platform YouTube focused on listening skills, this research was carried out by students from Pontificia Universidad Javeriana, Bogota Colombia its title is "El uso de videoblogs y sketches como material audiovisual auténtico para practicar la comprensión oral en inglés como segunda lengua, para estudiantes de nivel pre-intermedio de la licenciatura en lenguas modernas de la pontificia Universidad Javeriana". The authors identified situations through interviews with the students that gave them the starting point for their study, for instance, that listening skill was the skill studied the least in classes taught in the Modern Languages Degree at Pontificia Universidad Javeriana; similarly, most students do not feel able to understand a conversation between people who have a different accent from American and British accents and finally, the materials designed for academic purposes do not focus on providing authentic situations, since it is spoken clearly and at a slow pace which does not really 
prepare the students so that they can understand or develop in a real context (Méndez \& Londoño, 2016). Méndez and Londoño decided to create activities using video blogs and sketches as authentic audiovisual material to develop listening skills in English as a second language, for pre-intermediate students of the aforementioned career.

After the application of 3 sets of activities created by the authors and having analyzed the results found they concluded that most of the students surveyed consider that the activities proposed helped to improve listening skills; since it motivates them to be attentive to the details, they help them to learn new vocabulary, they prepare them to understand different accents and help them in pronunciation too; because they listen to native speakers (Méndez \& Londoño, 2016).

This research is quite close to ours since the authors emphasize the importance of using authentic material in the second language classes, and they highlight the characteristics of the sketches and video blogs found in the digital platform YouTube, that we identify as the fundamental characteristic of the videos of TED, which is the variety of accents, expressions, and words that can be found in these authentic videos; nevertheless, it should be noted that TED has an advantage over YouTube that is the correct subtitling and transcription of each video.

\subsection{Authentic Video}

As argued along this work, there should be an interest from English as a Foreign language teachers towards facing the students with real spoken English since the very beginning of the learning process, for that reason, authentic videos that are supposed to entertain or inform native speakers of the target language and are not supposed to be used to teach language, may become a powerful and useful tool inside the English as a foreign language classroom. This, considering that videos supply more information regarding the speaker and the context in which the speech is being given than just the audio, for example, and the appealing properties that these digital products have;

Thus, when talking about authentic videos, Bacon and Finnemann (1990) assert that any input produced by and for native speakers of the target language is considered authentic. It means that every content that originally was not made to teach a foreign language but to be consumed by native speakers, is an authentic material. Taking into account the definition of authentic, when talking about materials, given by Callison \& Lamb (2004) who define it as something that is "genuine, real, and true" (p. 34) it is worth to mention that it is exactly there where lies the relevance of the authentic videos; since these are to communicate ideas to native speakers using their daily vocabulary, their speed of speech, their idioms and more features of the daily language that are not found in the materials developed to learn English. This is supported by Talavan (2007a) who makes the following distinction: "Traditionally, two main uses of video have been distinguished: instructional video, specifically created to teach foreign languages, and authentic video materials, such as films, TV series, commercials, etc., originally created for native speakers of the language." (p. 2).

When referring to authentic material, Rodgers and Medley claim that it has to do with any language sample that reflects spontaneity in form as in the speech used by native speakers, besides the relevance of cultural and situational context. So, following Talavan (2007a) the visual dimension, is a significant feature of the authentic videos since it makes the understanding process easier thanks to the gestures and the context in which the situation is taking place. That is why most of the examples given when talking about authentic videos are movies, tv shows, series, and so on (Weyers, 1999; Metruk, 2018; Kim, 2015). In this way, video becomes a "multi-sensory medium" (Swaffar \& Vlatten, 1997). The fact that students can watch a movie or a tv show and at once relate it to what they have experienced, seen, or thought results in such a great attraction to them.

In addition, there is a bunch of studies that assure that authentic videos result in such a good strategy to be used in the foreign language classroom since it allows the student to feel more engaged and focused as well as an arise in the student's motivation (Bacon and Finneman, 1990; Weyers, 1999; Block, 1993; Kim, 2015; Metruk, 2018). Video-based instruction improves aspects of learners' oral production too, particularly their "confidence in speech" (Weyers, 1999).

On the other hand, there have been some other critics against authentic videos; for example, Talavan (2007b) mentions the fact that the language is not graded; hence, for beginners it will be harder to understand, which becomes in a contradiction with what we have been claiming, since the idea is to face the student with the real language, the language spoken out there with all the features, changes, and usages of it; However, it does not mean that this should not be considered. Activities, choice, and implementation carried out using videos must be carefully prepared in advance to get the best from them.

Therefore, authentic videos turn into a great ally when facing students to real spoken English given that they provide learners with more information about the context, the body movement and the manners when transmitting 
a message, which eventually will result in a more complete apprehension of what is said and, consequently, in a better introjection of the features of the language that, we think, will enable the student to express her/himself more confidently.

\subsection{Digital Platforms}

Even though the world of digital platforms is new, the incidence that these spaces have had over every single human activity is undeniable. Nowadays, 2.0 humans have the possibility to connect easily with anyone in any part of the world using the internet without thinking so much in the limits of time and space (Castells, 2000). Besides that, industries, consuming behavior and the way people are accessing information is changing thanks to the development of different technologies and internet that allow the users interact more easily with any instance in the society such as the government, other parts of the world and between them along with the education (Castells, 2014; Pampillón, 2009; Ruutu, Casey, \& Kotovirta, 2017; Valenzuela, Gonzalez, Rosas, \& Mellado, 2013). This widespread intrusion of technologies and its derivatives has led industries, entrepreneurs, politicians, and companies to take advantage and reach their goals using these tools; However, in this paper, we are focused on the use of digital platforms, specifically video digital platforms like TED, as a means that could help to face the challenges of English teaching.

In this sense, a definition of digital platforms is given considering their productive uses and the innovative aspect that currently is so important. Ghazawneh and Henfridsson (2015) define digital platforms as: "software-based external platforms consisting of the extensible codebase of a software-based system that provides core functionality shared by the modules that interoperate with it and the interfaces through which they interoperate." In other words, digital platforms are systems that have a core developer that distributes and shares information so that everyone who interacts with the platform can access and operate on it. Following this, platforms can be opened or closed to the public, for example, Linux or Apache and Facebook or YouTube. On this respect, Baldwin and von Hippel (2011) explain: "In the case of Apache, the platform is an open, collaboratively built one, and appended innovations are developed by innovators [...] In contrast, Facebook and YouTube are producer-built and producer-owned platforms, and appended creative content is generated primarily by individual users". Which allows us to suppose that TED is within the closed-type platforms and its content is developed to be shared with the public but produced by specific individuals.

From another perspective, digital platforms can be defined from a technical or socio technical point of view, depending on how the elements of the platform are organized, though there is a consensus in accepting that platforms involve both software and hardware (de Reuver, Sørensen, \& Basole, 2017). That is, digital platforms should have a physical support where to save the information along with digital networks that permit the interaction of users, and the spread of the information hosted in the servers. This goes along with Spagnoletti, Resca and Lee (2015) that suggest that digital platforms should be to connect and to ease sharing information around the world. In this sense, we consider that TED accomplishes most of the characteristics to be called a digital platform, without forgetting that it is found in different formats as the downloadable app for mobiles, and the web page which generates a facility to access to their content either for teachers or for students.

\subsection{TED}

Now, it is important to highlight that there are plenty of resources or digital platforms where we can find authentic videos that could help us to provide the students with the means to communicate using English; however, it is worthy to clarify that our interest in TED is because of its feature that brings the conference's transcription besides the characteristic that every video has its own subtitles that are not auto-generated as it happens with many videos on YouTube, for instance.

With this in mind, we can tell that TED is a non-profit organization, whose headquarters are located in Silicon Valley. It was founded in 1984 as a conference covering Technology, Entertainment, and Design that was supposed to be every year (Ted.com, 2016a). The talks have an extension of between ten to twenty minutes long and are uploaded to be seen via the internet, directly from the web page, or through the mobile app. Nowadays, TED's topics have expanded to include science, business, and global issues, that is why the success of TED has boomed, being translated into over 100 languages (Ted.com, 2016a), and celebrating over one billion views (Ted.com, 2016b).

Ideas worth spreading is the logo of TED, which in other words means that the purpose of this platform is to share the knowledge (Ted.com, 2018a), through conferences given by some experts in the area. Similarly, following the words of Quizhpi (2015) TED's aims are turning a negative idea into a positive one, educating people in different topics, motivating and inspire people to carry out with their ideas (p. 27). This makes TED one excellent tool inside the classroom of ELT since this not only allows to interact with spoken English but also getting a perspective from 
the side of people with expertise in the particular area. The significant impact that TED has had over education is remarkable; given that, for instance, in English teaching, along with the vocabulary learning, there is a component of thinking about the topics that affect the society and the world in which we are living. Along with this spread-knowledge aim comes the fact that it is done strikingly, or in words of Chris Anderson, the owner of the organization, through the "wow" factor (Trost, 2010).

Some articles cited by Wingrove (2017) show the criticism against TED; However, in his study, he finds that TED is useful in an academic context given the features of the platform and its content; Besides that, TED becomes an excellent pedagogical tool thanks to its "ability to wow, inspire, and amaze an audience. As well as being able to search by tag; additionally, TED allows videos to be sorted by rating: jaw-dropping, funny, courageous, inspiring, and so on." (p. 2) These characteristics make TED an easy-to-use and powerful means to share and discuss a myriad of issues with the students, developing not just their communicative skills but also their ability to face critically what they are watching.

Unlike some other digital video platforms, that were not designed for teaching purposes, TED offers the possibility to see the proper subtitles of the conferences, and its corresponding transcription (Saunders, 2017), which allows the students to gather the information either listening or reading and in an integrated manner as they can see the gestures, and the movements of the speakers which give much more information to the listener. For this reason, our interest is focused more on TED than on other video platforms, which are developed to be used in an English teaching environment or do not have the complete characteristics that TED has. It is worthy to highlight also the fact that given the first impact that TED had over education, it has agreed on some partnerships with other companies, such as NatGeo, and has developed their own platform for education (Saunders, 2017; Wingrove, 2017)

In this manner, the implementation of such a strategy with this platform is related with the variety of people who share their knowledge in each conference, people who come from distinct parts of the world, which widens the spectrum of accents, manners, idioms, and characteristics unique from each variant of English. Likewise, it is worthy to highlight the fact that most of the topics treated in TED's conferences have a social, cultural, academic, or political content which lets the students acquire not just the language's features but also prepare themselves to debate and not only express but defend their ideas.

\section{Methodology}

This study will be based on qualitative action research which is a methodology that includes action and research. McKay (2006) establishes that action research involves a systematic inquiry into the issues and problems that teachers face aiming to improve pedagogical practices. As mentioned before, we evidenced a problem in the classroom concerning the communicative competence of the students and the lack of technology implementation in the classroom. That being said, it is important to highlight that we do not only want to observe the phenomenon and try to understand it but also, as practitioners, we want to make a real immersion in the classroom through the implementation of certain activities that have been based on authentic videos of the digital platform TED, in order to reflect and improve our pedagogical practices; in this manner, as teachers concerned about the methodologies used in the classroom and its results as well as the problems that arise there, the action research method is the most suitable for responding to the research question that guides our study.

\subsection{Data Collection Instruments}

There are many data collection instruments used in qualitative research, where each one has special characteristics to obtain diverse types and quantities of information. Considering the research question that we seek to answer we have chosen three methods of data collection for their accuracy.

\subsubsection{Interview}

The interview is a particularly useful data-collection tool because of the information that can be accessed through it. A qualitative interview, according to Tashakkori and Teddlie (2010), "is unstructured, exploratory. open-ended, and typically in-depth so that several topics can be explored effectively." (p. 305) That means the interviewee is free to answer the open-ended questions without being judged by the interviewer.

This instrument is important because through it we get all the information that we do not get by observing (Cerda, 1991) and given that the opinion and perspectives of the participants are of significant importance to us as researchers.

An interview was implemented in two moments with the head teacher, at first that was at the beginning of the research to know their vision about technological tools' implementation inside the EFL classroom, what kind of materials she uses in her classes, as well as there is an interest in how she perceive students' participation and their 
communicative performance, to know her experiences in previous years along with her impressions regarding a new way to assume the English teaching in a more structured way; the interview was applied in a second moment that was at the end of the pedagogical intervention to know the perspective of the teacher about the process that could be observed during the application of the activities with the videos, the attitude of the students, their participation, and their interaction and performance in the foreign language, taking into account that she was present in all the classes.

\subsubsection{Questionnaire}

Marshall (2006) argues that "Researchers administer questionnaires to some samples of a population to learn about the distribution of characteristics, attitudes, or beliefs" (p. 125); Therefore, the questionnaire appears as a convenient instrument that allows us to deepen more the respective thoughts of each of our participants regarding English as a Foreign Language since it allows the person who is answering to express more freely what is in their minds.

The questionnaire, like the interview, was applied in two moments, at the beginning and at the end of the pedagogical intervention. At the beginning, was important to know about students' feelings, experiences, perceptions, perspectives, beliefs, likes, and dislikes related to the English learning process, and their relationship with technologies as well as digital platforms, and then, we were interested in knowing how they felt during the activities implemented based on TED talks, which they liked most, and how they now perceive their relationship with English as a foreign language.

\subsubsection{Teacher Journal}

As a method to collect information and evidence of the teaching-learning process we choose the teacher journal, because of its characteristics we believed it is a valuable tool that allows us to capture everything that happened in the classroom, because we meticulously and periodically record the observed facts during the class.

The journals allowed us to reflect on our pedagogical practice, since in the notes that are written there, the different variables that affect the class are related, such as the resources used, the students' response to the proposed activities, the results in comparison with the proposed goals, and of course our performance as teachers.

Furthermore, detailed review of the journals allowed us to make important decisions because depending on what we observed there, how the process was taking place in the class, we could modify, or on the contrary, emphasize on strategies, resources, activities, etc.

\subsection{Participants}

This investigation was carried out in a public school located in Bogota Colombia with 31 students from eleventh grade whose ages range between 16 and 18 years old, they are 15 girls and 16 boys.

They have taken English classes at school for at least 6 years, and most of them have an interest in learning different languages.

\subsection{Set of Activities}

The pedagogical intervention was made up of four sessions, that is, one each week during the month of May 2018. Every session was constructed based upon the principles of the Task-Based Approach, namely, pre-task, task cycle and language focus (Richards \& Rodgers, 2001) that in our study were known as pre-watching, watching and after watching activities. For each session we selected a TED talk according to the information collected through the questionnaire about students' preferences; in addition, the videos were selected considering the speaker's accent, the pace of speech and, video duration (no more than 8 minutes).

In the pre-watching the subject was introduced, students got prepared for what they were going to see, hear and do. Activities such as brainstorming, word-searching and, crosswords were carried out which supplied key vocabulary and activated previous knowledge. After this, the video was played.

During the watching, the students did exercises such as taking notes of unknown words or words that summarize the conference. This, to develop activities where the language was used in oral and written form, for instance: after writing down important vocabulary from the TED talk some students did role plays. We also planned activities in small groups, for example, after watching the video, in groups of 5-6 people each group discussed what they watched, who was the presenter, why they gave the speech, how effective was it: encouraging them to ask each other questions and share opinions. The teachers were a facilitator guide when his/her help was needed, for the rest, the teachers were observers. Finally, in the post-task students presented their resolved task, they were role plays, posters, and debates. 


\section{Results and Analysis}

In the following lines the findings of this study are going to be presented according to certain categories established by the researchers to make easier the understanding of the incidence of TED talks on the students' performance in English class.

\subsection{Students' Participation}

Since videos have cultural, social and, political content students felt encouraged to speak. They showed more critical and reflexive thinking regarding different topics in the society. Students were more prone to comment on the topics as well as they were more motivated in expressing what they were thinking, in addition, they were more open to sharing their ideas with others. Besides that, given that speaking a language goes beyond expressing ideas but thinking about them and having a position regarding those ideas, students could take advantage from the speakers' experience to assume and defend what they believed about a particular topic.

Evidence of the above was found in the teachers' journals that narrated how in one of the sessions students defended their position in a debate using many expressions taken from the speech.

Given the paradigm change, students felt motivated to participate in English class. Because of the use of new tools, students started to see the English class as something that actually called their attention. For example, one of the students that answered the second questionnaire asserted that "I like more the English class now because we are not learning structures and formulas from a book, but we are watching interesting speeches and we are listening to people who already speak the language." This is supported by the headteacher who claims, in the second interview, that "I'm impressed to see how students want to participate in the English classes and everyone attempts to speak when time before just the same three students spoke."

\subsection{Engagement Towards English Learning}

Students expressed that they felt more comfortable doing the activities proposed thanks to the talks since they offered the possibility to gather words that (1) are normally used in the spoken language, (2) are easy to use in context, and (3) are related with their life, since they were the ones who chose the topic. Students also remarked the fact that most of the themes in TED talks are socially and culturally relevant. The headteacher pointed out this better in the attitude towards the activities in English based on the videos. She stresses the fact that when other activities used to be assigned, students were reluctant to do them; students were careless about what was going on in the English class; instead, when TED talks were presented students got their complete attention to understand what the speaker was saying and use the words caught to express what they were thinking.

\subsection{Language Awareness}

Learners communicated with their partners using the words in the proper context and more confidently thanks to the vocabulary and the exposure to which they were subject. In addition, students claimed they felt more confident speaking since they already counted with the elements that allowed them to express their ideas, their feelings and, their standpoints regarding socio-cultural topics.

Students noticed that there are diverse ways to pronounce the language; therefore, it is not a reason to quit speaking. Some learners declared that they thought the only pronunciations to speak English were American and British and realizing that around the world there are singular ways to speak encourages to do so. According to one of the students, "it doesn't matter how to pronounce but to be understood."

\section{Conclusions}

TED talks prove to be a useful material for English teaching as a foreign language considering that they assemble many characteristics that catch students' attention and get them related with the language spoken in actual contexts. One of the main points made when using TED talks is that students are not just listening to the speaker, that is what would happen in a recording, but they are watching the speaker's movements and facial expressions that permit the students to gather much more information about the speech and include it in their repertoire to use it in future occasions. Another aspect to remark is the accuracy of TED subtitles that, additionally, give more information to the students about what they are listening, as well as let the students gather much more words, meaning vocabulary than they would catch if just listening.

In addition, the fact that the speakers in TED talks come from all around the world lets the students realize that learning English goes beyond doing a perfect pronunciation, but it also includes using the language to express ideas no matter if it is correct or no, perfection will come with the practice. At first stages, the important thing is to try. This gets the students related with more pronunciations besides American and British which eventually will create confidence in the students because they will not pay as much attention as they would pay to the content of 
what they are saying. With this, we are not declaring that pronunciation is unimportant, we are trying to make the point that students should not be afraid of speaking just because they do not pronounce perfectly American or perfectly British.

Additionally, socio-cultural topics contained in the TED talks add to the motivation and interest of the students to participate actively in the proposed activities. Given that we used talks about disabilities like autism, addictions to hallucinogenic substances, and environmental issues, the students felt identified with these concerns finding them as relevant topics for their context, encouraging them to share their opinions in an oral and written way. Something important to remark is that during the English class it is important to promote the use of the target language to the extent possible and using topics that concern the students is an effective way to do it. With this, the idea is to create an environment in which the students get related to the target language and doing so, create a path to learn it meaningfully. Creating such an environment is quite important because those few hours that the students are in English class is possibly the only time that they are in contact with the language.

One more aspect to highlight is how convenient is the use of ICT's in the English classroom, considering that nowadays most of the students are more prone to pay attention to a screen than to a board it would be better if as teachers we make of those devices an ally more than an enemy. Maybe the traditional elements, like the board or the course books can be used too but as complement to the other tools and not as the only resources available.

Finally, considering that there were some aspects that were not considered in deep in this research, we propose that further investigation could be focused on how the TED talks promote other skills such as critical thinking, citizenship abilities, and $21^{\text {st }}$-century skills. Likewise, further investigation with other platforms as authentic material could be considered.

\section{References}

Arias Soto, L., \& Buitrago Escobar, Z., \& Pineda Báez, C. (2011). ICT in the professional development of EFL teachers: perceptions and challenges. Revista Folios, 33, 25-42. https://doi.org/10.17227/012348 70.33 folios 25.42

Bacon, S. M., \& Finneman, M. D. (1990). A study of the attitudes, motives, and strategies of university foreign language students and their disposition to authentic oral and written input. The modern language journal, 74, 459-73. https://doi.org/10.1111/j.1540-4781.1990.tb05338.x

Baldwin, C., \& von Hippel, E. (2011). Modeling a Paradigm Shift: From Producer Innovation to User and Open Collaborative Innovation. Organization Science, 22(6), 1399-1417. https://doi.org/10.1287/orsc.1100.0618

Bianchi, F., \& Marenzi, I. (2015). Teaching and investigating higher-level comprehension skills in LearnWeb, an interactive platform integrating TED Talks (pp. 236-240). In Conference Proceedings, ICT for Language Learning, Florence, Italy.

Block, D. (1993) Authentic Video and Classroom Observation. System, 21(1), 49-67. https://doi.org/10.10 16/0346-251X(93)90006-3

Callison, D., \& Lamb, A. (December 2004). Keywords in Instruction: Authentic Learning. School Library Media Activities Monthly, 21(2),34 -39.

Castells, M. (2000). El poder en la sociedad red. En Comunicación y poder (pp. 33-86). Alianza Editorial, Madrid.

Castells, M. (2014). El impacto de internet en la sociedad: Una Perspectiva global. In La sociedad, la comunidad, las personas. BBVAOpenMind, Retrieved from https://www.bbvaopenmind.com/articulo/el-impacto-deinternet-en-la-sociedad-una-perspectiva-global/

Cerda, H. (1991). Los elementos de la Investigación Bogotá: El Búho.

Cruz Suárez, E. (2014). Technologies for EFL beginners the video as a technological resource that allows the design of adequate material to initiate learning processes in EFL for first-grade students at Prado Veraniego School.

de Reuver, M., Sørensen, C., \& Basole, R. (2017). The digital platform: a research agenda. Journal of Information Technology, 1-12.

Derechos Básicos de Aprendizaje: inglés. (2016). Ministerio de Educacion nacional, Colombia.

Estándares Básicos de Competencias en Lenguas Extranjeras: ingles (2006) Ministerio de Educacion nacional, Colombia.

Ghazawneh, A., \& Henfridsson, O. (2015). A Paradigmatic Analysis of Digital Application Marketplaces. Journal 
of Information Technology, 30(3), 198-208. https://doi.org/10.1057/jit.2015.16

Henríquez, P., Moncada, G., Chacón, L., Dallos, J., \& Ruiz, C. (2012). Nativos digitales: aproximación a los patrones de consumo y hábitos de uso de internet, videojuegos y celulares. Revista Educación y Pedagogía, 24(62), 145

Kim, H. (2015) Using Authentic Videos to Improve EFL Students' Listening Comprehension. International Journal of Contents, 11(4), 15-23. https://doi.org/10.5392/IJoC.2015.11.2.015

La república (noviembre, 2016). Colombia se raja en el índice de dominio de inglés Education First. La republica Retrieved from https://www.larepublica.co/globoeconomia/colombia-se-raja-en-el-indice-de-dominio-deingles-de-education-first-2443756

McKay, S. L. (2006). Researching second language classrooms. Routledge.

Mejía Jálabe, A., Villarreal Mora, C., Silva Giraldo, C., Suarez Suarez, D., \& Villamizar Niño, C. (2015). Estudio de los factores de resistencia al cambio y actitud hacia el uso educativo de las TIC por parte del personal docente. Revista Boletín Redipe.

Méndez Ospina, A., \& Londoño Santos, N. (2016). El uso de videoblogs y sketches como material audiovisual auténtico para practicar la comprensión oral en inglés como segunda lengua, para estudiantes de nivel pre-intermedio de la licenciatura en lenguas modernas de la Pontificia Universidad Javeriana.

Metruk, R. (2018). The Effects of Watching Authentic English Videos with and without Subtitles on Listening and Reading Skills of EFL Learners. EURASIA Journal of Mathematics, Science and Technology Education, 14(6), 2545-2553. https://doi.org/10.29333/ejmste/90088

Pampillón, A. (2009). Las plataformas e-learning para la enseñanza y el aprendizaje universitario en Internet. In Las plataformas de aprendizaje. Del mito a la realidad (pp. 45-73). Biblioteca Nueva, Madrid.

Quizhpi Picón, A. L. (2015). TED talks as a mobile-learning tool to enhance speaking skills in ninth graders at the American School (Bachelor's thesis).

Resultados agregados puntajes promedio Saber 11 2017-2 (2017). Instituto colombiano para la evaluación de la educación. ICFES.

Richards, J., \& Rodgers, T. (2002). Approaches and Methods in Language Teaching (2nd ed.). Cambridge University Press, UK. https://doi.org/10.1017/CBO9780511667190

Rodgers, C., \& Medley, F. (1988). Language with a Purpose: Using Authentic Materials in the Foreign Language Classroom. Foreign Language Annals, 21, 467-78. https://doi.org/10.1111/j.1944-9720.1988.tb01098.x

Ruutu, S., Casey, T., \& Kotovirta, V. (2017). Development and competition of digital service platforms: A system dynamics approach. Technological Forecasting \& Social Change, 117, 119-130. https://doi.org/10.1016/j.te chfore.2016.12.011

Saunders, T. (2017). A Brief Catalogue and Review of Key Online Video Resources and Platforms, Tamagawa University, Center for English as a Lingua Franca Japan.

Spagnoletti, P., Resca, A., \& Lee, G. (2015). A design theory for digital platforms supporting online communities: a multiple case study. Journal of Information Technology, 30, 364-380. https://doi.org/10.1057/jit.2014.37

Swaffar, J., \& Vlatten, A. (1997). A sequential model for video viewing in the foreign language curriculum. Modern Language Journal, 81(1), 175-188. https://doi.org/10.1111/j.1540-4781.1997.tb01173.x

Talavan, N. (2007a). Using subtitles in a multimedia environment to enhance listening comprehension for foreign language students of English. Proceedings VI International AELFE Conference. Lisboa: ISCAL: 452-458.

Talavan, N. (2007b). Learning Vocabulary through Authentic Video and Subtitles. TESOL-SPAIN Newsletter, 31, $5-8$.

Tashakkori, A., \& Teddlie, C. (Eds.). (2010). Sage handbook of mixed methods in social \& behavioral research. Sage. https://doi.org/10.4135/9781506335193

Ted.com. (2016a). Our organization j About j TED. Retrieved 25 Apr 2018, from http://www.ted.com/about/ our-organization

Ted.com. (2016b). History of TED j Our organization j About j TED. Retrieved 25 Apr 2018, from http://www.ted.com/about/our-organization/history-of-ted

Trost, M. (2010). AMA: TED's Chris Anderson answers Reddit's questions right here. TED Blog. Retrieved 26 
April 2018, from http://blog.ted.com/teds_chris_ande_3/

Valenzuela, G., Gonzalez, A., Rosas, J., 7 Mellado, D. (2013)。 Análisis y reflexión de la plataforma electrónica y el aprendizaje virtual. Cuerpo Académico "Derecho, Participación Ciudadana, Anticorrupción, Educación y Desarrollo Humano Comunitario e Institucional". Universidad de Sonora, Año 1, No. 1.

Weyers, J. (1999). The effect of authentic video on communicative competence. Modern Language Journal, 83(3), 339-353. https://doi.org/10.1111/0026-7902.00026

Wingrove, P. (2017). How suitable are TED talks for academic listening? Journal of English for Academic Purposes, 30, 79-95. https://doi.org/10.1016/j.jeap.2017.10.010

\section{Copyrights}

Copyright for this article is retained by the author(s), with first publication rights granted to the journal.

This is an open-access article distributed under the terms and conditions of the Creative Commons Attribution license (http://creativecommons.org/licenses/by/4.0/). 